\title{
Lisinopril Anhydrous
}

National Cancer Institute

\section{Source}

National Cancer Institute. Lisinopril Anhydrous. NCI Thesaurus. Code C83924.

The anhydrous form of the long-acting angiotensin-converting enzyme (ACE) inhibitor lisinopril with antihypertensive activity. Lisinopril, a synthetic peptide derivative, competitively binds to and inhibits ACE, thereby blocking the conversion of angiotensin I to ang iotensin II. This prevents the potent vasoconstrictive actions of ang iotensin II and results in vasodilation. Lisinopril also decreases ang iotensin II-induced aldosterone secretion by the adrenal cortex, which leads to an increase in sodium excretion and subsequently increases water outflow. 